\title{
Critical Thinking Disposition: Students Skeptic in Dealing with Ill-Logical Mathematics Problem
}

\section{Purna Bayu Nugroho}

Teacher in STKIP Muhammadiyah Kotabumi, Indonesia,purnabayupvz@gmail.com

\section{Toto Nusantara}

Prof., State University of Malang, Indonesia, toto.nusantara.fmipa@um.ac.id

\author{
Abdur Rahman As'ari \\ Dr., State University of Malang, Indonesia, abdur.rahman.fmipa@um.ac.id
}

\author{
Sisworo \\ Dr., State University of Malang, Indonesia, faizalr@usm.my
}

\section{Erry Hidayanto}

Dr., State University of Malang, Indonesia,erry.hidayanto.fmipa@um.ac.id

\section{Susiswo}

Dr., State University of Malang, Indonesia, susiswo.fmipa@um.ac.id

$$
\text { (a) }
$$

One characteristic of a person having a critical thinking disposition is engaging in the activity with reflective skepticism. Skeptical attitudes can encourage a person to reflect so as to produce a correct conclusion and make the right decision. This article aims to determine: (1) the cause of students skeptic in dealing with illlogical mathematics problem and (2) the phase involved in skeptic and decision making on ill-logical mathematics problem. This research is a qualitative research with explorative descriptive research type. The subject of this study consisted of two students who were skeptical of ill-logical mathematics problem. The data were collected through a test, direct observation, and interview. The results of data collection were analyzed through data reduction stage, data presentation and conclusion of findings. The results of this study indicate that: (1) there are two causes of skepticism: (a) the presence of cognitive conflict and (b) the presence of two conflicting outcomes; (2) the phases involved in skepticism and decision making on the Ill-logical Mathematics problem from stimulus, skeptic, reflective, and decision making.

Keywords: critical thinking disposition, Ill-logical mathematics problem, skeptic, critical thinking, mathematic

Citation: Nugroho, P. B., Nusantara, T., As'ari, A. R., Sisworo, Hidayanto, E., \& Susiswo (2018). Critical Thinking Disposition: Students Skeptic in Dealing with Ill-Logical Mathematics Problem. International Journal of Instruction, 11(3), 635-648. https://doi.org/10.12973/iji.2018.11343a 


\section{INTRODUCTION}

Critical thinking is a very important thing for everyone (Angeli and Valanides, 2009; As'ari, Mahmudi, and Nurlaelah, 2017; Bell and Loon, 2015; Biber, Tuna, and Incikabi, 2013; Bie, Wilhelm, and Meij, 2015; Chen, Tolmie, and Wang, 2017; Cheng, May, and Wan, 2017; Ku, Lee, and Ellis, 2017; Özkahraman, 2012; Udi and Cheng, 2015). Critical thinking is a type of thinking involved in solving problems, formulating conclusions, counting possibilities, and making decisions (Taube, 1997). Angeli and Valanides (2009) stated that critical thinking is required by of every citizen of the democracy to deal with a large number of ill-defined information and problems filled with uncertainty. It was confirmed by As'ari that critical thinking can make better and more appropriate decisions in responding to information (As'ari et al., 2017). Based on the information, it is appropriate to think critically as an important foundation in education to face the $21^{\text {st }}$ century (Cheng et al., 2017). Some scholars distinguish critical thinking into two: the ability and disposition of critical thinking (Bell \& Loon, 2015; Cheng et al., 2017; Ennis, 2011; Facione, 2000; Taube, 1997).

Critical thinking skills are useless if they are not used (Taube, 1997). An individual needs the appropriate critical thinking disposition to use that ability (Bell \& Loon, 2015). The disposition of critical thinking is a consistent internal motivation to involve problems and make decisions through the use of critical thinking (Bell \& Loon, 2015; Facione, 2000) and is a measure of the tendency toward critical thinking (Bell \& Loon, 2015). One must have the disposition to productively and critically think about the problem (Taube, 1997). Some researchers describe the characteristics of a person that is said to have a critical thinking disposition.

The characteristics of a person that is said to have a critical thinking disposition are divided into two things: (1) related to life and life in general and (2) related to specific problems, questions and problems. The characteristics of a person that is said to have a critical thinking disposition are related to life and life in general: (a) being curious (As'ari et al., 2017; Facione, 1992; Özkahraman, 2012), (b) seekings to always be informed (As'ari et al., 2017; Facione, 1992; Özkahraman, 2012), (c) being ready to always use critical thinking (As'ari et al., 2017; Facione, 1990; Özkahraman, 2012), (d) believing in the process of reasoned investigation (Facione, 1990), (e) confidence (As'ari et al., 2017; Facione, 1990), (f) open thinking (As'ari et al., 2017; Facione, 1990; Özkahraman, 2012), (g) flexibility (As'ari et al., 2017; Facione, 1990; Özkahraman, 2012), (h) understanding the opinions of the others (As'ari et al., 2017; Facione, 1990), (i) being objective or fair minded (As'ari et al., 2017; Facione, 1990; Özkahraman, 2012), (j) sage (As'ari et al., 2017; Facione, 1990), (k) being willing to reconsider and revise if necessary (As'ari et al., 2017; Facione, 1990) and (l) Honest (Facione, 1990). The characteristics of a person who has a critical thinking disposition are related to a particular problem, question or problem namely: (a) clarifying the clarity of a problem; (b) being diligent in searching for relevant information (c) rational in selecting and applying criteria; (d) ordering (in order) in working on complex issues; (e) focusing on the main concerns; (f) persevering despite difficulty (never giving up); ( $\mathrm{g}$ ) careful consideration of subjects and circumstances (Facione, 1990). Based on these 
characteristics, a person with a critical thinking disposition tends to engage in the activity with reflective skepticism (Cheng et al., 2017; Facione, 1990).

Skeptics is an attitude of doubt, so skeptics always hesitates or does not believe in something they receive. People who have a critical-thinking disposition tend to be reflective in their reflection of everything they receive including the information regarding a problem. As'ari and Irawan (2016) assert that a person who has a critical thinking disposition will not accept any information given away without any attempt to gain confidence in its truth. On the basis of these statements, skepticism is a significant aspect of critical thinking disposition so that further research is needed on skeptics, especially in the face of ill-defined problems.

Ill-defined problems are often called ill-structured problems or messy problems (King \& Kitchener, 1994). Ill-defined problems are a problem with ambiguity and ambiguous goals (Hocking \& Vernon, 2017). Furthermore, ill-defined problems are divided into three types of problems: (1) problems with ambiguous (open-ended) information (As'ari et al., 2017; Douglas, Koro-ljungberg, Mcneill, Malcolm, \& Therriault, 2012; Hocking \& Vernon, 2017; Lynch, Ashley, Pinkwart, \& Aleven, 2009), (2) problems with incomplete information (As'ari et al., 2017; Lynch et al., 2009) and (3) problems in which there is information conflict (contradictory information) (As'ari et al., 2017; Douglas et al., 2012; King \& Kitchener, 1994).

Ill-defined problems, in which there is an information conflict, are also called ill-logical problems by As'ari et al. (2017). Based on the results of the ill-logical problem done by As'ari et al. (2017) to some mathematics teacher candidates, it is found that the prospective teacher is at the level of emergent critical thinker. In his research, As'ari et al. (2017) divided the level of critical thinking based on the prospective teacher's critical thinking disposition in solving mathematical problems and concluded that some prospective teachers are at the lowest critical thinking level.

Based on the conclusion in As'ari's research, the question arises is how about the critical thinking position of a 13-year-old child? Should not a person's critical thinking begin to emerge from the age of 13? Piaget (Simatwa, 2010) stated that children at the age of 13 are at a formal operational stage. At the formal operational stage, the child think logically and systematically, draw conclusions, interpret and develop hypotheses. Supposedly since the age of 13 years, the child has developed the ability of critical thinking so that the disposition of critical thinking can also emerge. Based on the preliminary observations, the 13 -year-olds child, in this case, is still dominated by junior high school students (SMP) of class VIII who do not yet have critical thinking dispositions. It appears that students simply take for granted the information provided without first reflecting on the truth of the information provided. Whereas the students have a critical thinking disposition will not receive any information given away without any attempt to gain the confidence with its truth (As'ari \& Irawan, 2016). It could be seen from 90 students who were given an ill-logical mathematics problem (see Figure 1.a) and gave similar (see Figure 1.b) as follows: 


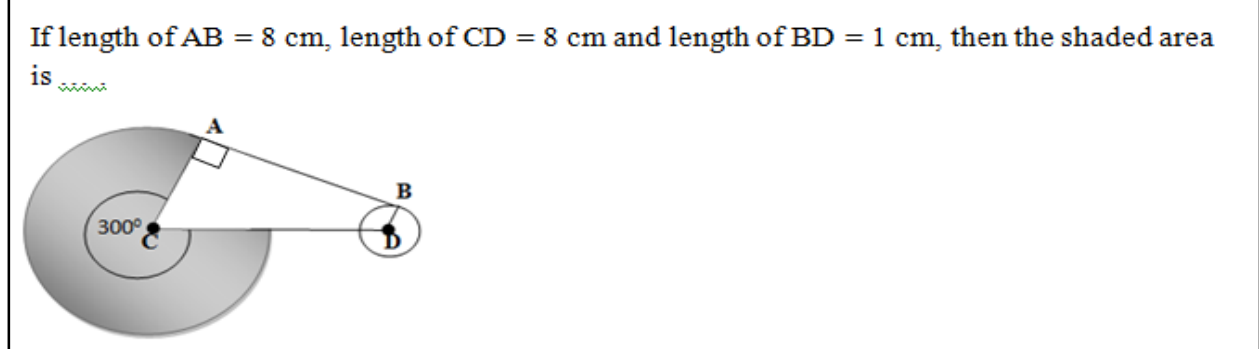

Figure 1.a

A snippet of student's response to the Ill-logical Mathematics problem is shown in Figure 1.b as follows.

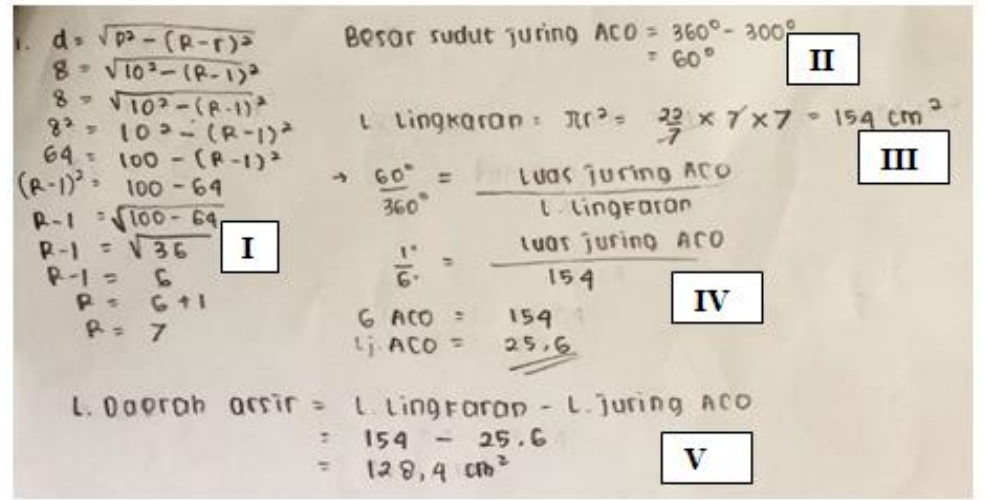

Figure 1.b.1

A snippet of student's answers on initial observations

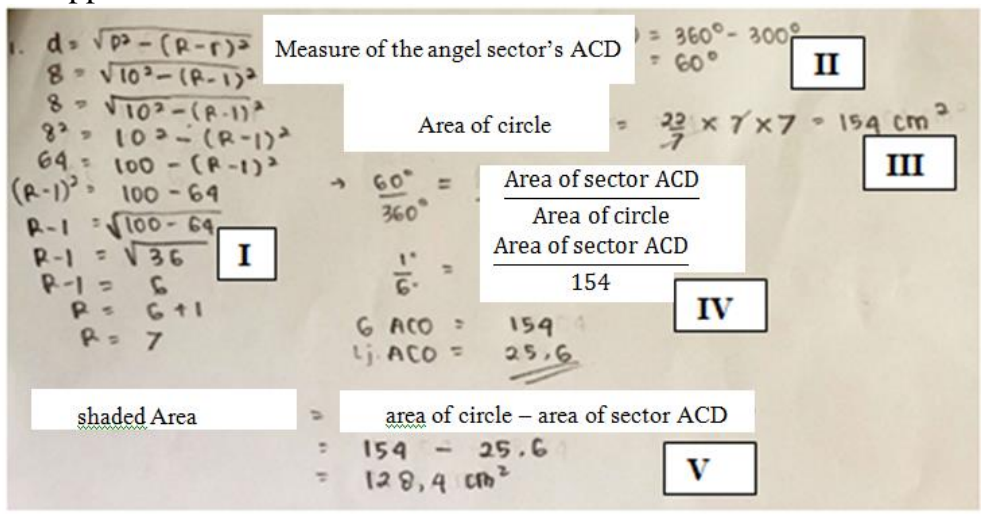

Figure 1.b.2

Translation of Figure 1.b.1

International Journal of Instruction, July $2018 \bullet$ Vol.11, No.3 
In Figure 1.b.1, the step I of the students is to find the length of the radius using Pythagoras theorem so that it results in the length of radius $7 \mathrm{~cm}$. The next step, the student uses the result from step I in step II to step V. The student ignores the known $300^{\circ}$ angle in the search for the radius, so that the angle formed by the $\mathrm{AB}$ and $\mathrm{CD}$ lines is $60^{\circ}$ not used in determining the length of the radius. If the student uses the angle to determine the radius then it is impossible to obtain the $\mathrm{AB}$ line length of $7 \mathrm{~cm}$. Based on the information it appears that the students are not skeptical of the information provided. It is apparent from the students who do not focus on all the information available and based on the timing of the given problem, the students quickly collect their work before the time runs out without reflecting on the calculations that have been made. Once the importance of skepticism in responding to ill-logical mathematics problem to help students do what must be done, it is necessary to do a study of students' skepticism in the face of ill-logical mathematics problem. This article aims to determine: (1) the cause of students' skepticism in dealing with ill-logical mathematics problems and (2) phases involved in skepticism and decision making on the Ill-logical Mathematics problem.

\section{METHOD}

\section{Design}

This research is a qualitative research with explorative descriptive type. It is said a descriptive research because the researcher conducted the analysis only to the level of description, that is analyzing and presenting the facts systematically (Azwar, 2010). The study describes the skeptic of ill-logical mathematics problem.

\section{Materials.}

The main data of this research were written and the oral answers were obtained from the use of auxiliary ill-logical mathematics problem test instrument and interview. The given ill-logical mathematics problem contained conflicting information between $300^{\circ}$ angles and the length of the $\mathrm{CD}$ line and the length of the BD line (see Figure 1.a). The data resulted from the interview were used to validate the data. The validation of the data in this study using member checking was to ask the participants related to the description of responses that have been done by conducting interviews (Creswell, 2015).

\section{Participants}

The subjects of this study consisted of two students. Both students are from SMP N 03 Malang and SMP N 01 Salam Magelang. The selection of study subjects was based on the criteria namely: (1) the first middle school students were 13 to 14 years old, (2) the could communicate their thoughts both orally and in writing, and (3) the students were skeptical of the ill-logical mathematics problem.

\section{Procedures}

In this study, 92 students aged 13 to 14 years old that could communicate their thoughts both orally and in writing were selected from several schools. The selection is based on the recommendations from teachers who teach them. The selected students (92 students) were given ill-logical mathematics problems at different times according to the schedule 
given by their teachers. From the 92, the students who were skeptical of the truth of the ill-logical mathematics problem were selected. Furthermore, two students were skeptical of the ill-logical mathematics problem. Both students were asked to explain the reason for their skepticism toward the ill-logical mathematics problem in writing. From the results of the written reason, an interview was conducted to validate the data that has been obtained and then the data were analyzed.

\section{Data Collection Methods}

The data were collected through a test. The test was conducted to determine the students'response to ill-logical mathematics problem. At the time of the test, the students' gestures and facial expressions were observed carefully using live observation and video recording. The tests and observations were conducted to determine the research subject based on the criteria of the students who were skeptical while dealing with ill-logical mathematics problem. After the subject was found, a depth interview was done related to the students' response in facing ill-logical mathematics problem. The results of indepth interviews, test and observations were analyzed.

\section{Data Analysis}

The valid data were used to understand the cause of the students'skeptical attitude in dealing with ill-logical mathematics problem and to know the phase involved in skeptical attitude and decision making on ill-logical mathematics problem. The process of analysis was done in three stages, namely (1) data reduction by choosing the main things by focusing on the necessary things and removing unnecessary ones; (2) data presentation constituting a grouping stage of data that has been reduced into two groups: (a) the cause of skeptical attitude and (b) the phases involved in skeptic and decision making on the ill-logical mathematics problem; (3) the conclusion of the results of the deduced findings and data presentation.

\section{FINDINGS}

\section{The First Subject}

The first subject is skeptical of the ill-logical mathematics problem. The students asked to researchers about the data in the problem, because he felt there was something wrong with the problem. These doubts arose before the students wrote the answers in writing. Skeptical attitude is apparent with the question of the truth of the given problem. Here is a question stating that the students asked the truth of the given problem.

\section{S1 : Sir, what's the matter with this?}

Based on these questions, the researcher asked the students then they answered as follows:

$P \quad:$ why did you say that?

S1 : This looks strange sir. When I learned a special angle in triangles would not be like this. (1) This angle is $300^{\circ}$ (see figure 2), (2) means this angle is $60^{\circ}$ while (3) these sides are $8 \mathrm{~cm}$ and $10 \mathrm{~cm}$ (while showing the angles and sides in the given problem). So impossible. 


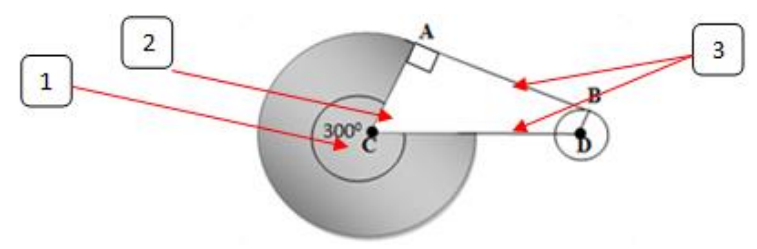

Figure 2

Images designated by students when interview

Then the student was asked to write down the explanation he presented on a paper, Figure 3 below shows an explanation of what he said.
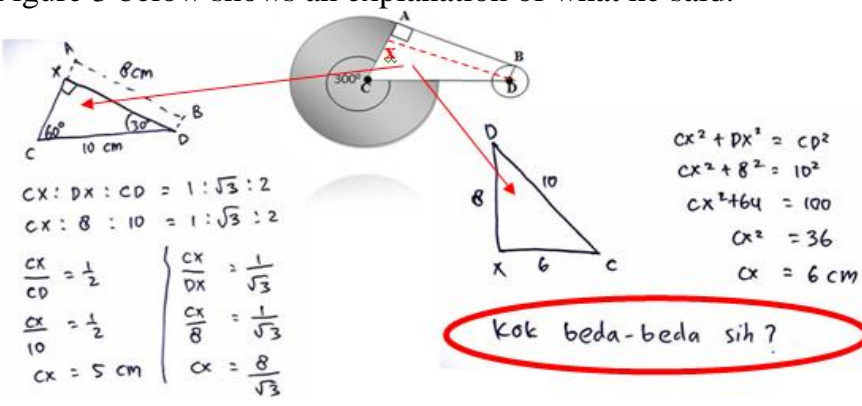

$c x=6 \mathrm{~cm}$

why is this different?

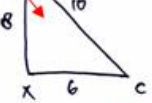

(b).Translation of (a)

Figure 3

Student's written reason in stating that sthare is connflicting information in the given problem.

In Figure 3.a., the students calculated the length of the CX line by using the principle of the ratio of side lengths in right triangles that have a large angle of $30^{\circ}, 60^{\circ}$ and $90^{\circ}$ so that the length of CX is $\frac{\mathrm{g}}{\sqrt{\mathrm{a}}} \mathrm{cm}$ and $5 \mathrm{~cm}$. Figure $3 . \mathrm{b}$ shows that the students calculated the length of CX by using the Pythagoras theorem based on known line length so that obtaining the length of CX $6 \mathrm{~cm}$. Based on the difference in the results of the two calculations that have been done then the students wrote the question as seen in the red circle in Figure 3.b. Based on the question marked with a red circle in Figure 3.b, then the student was asked "Are you sure that the result is different?".

\section{S1 : Yes Sir, I have counted many times but the result is still different}

The students assumed that the given problem is wrong so that the student does not proceed to count the shaded area as desired in the question.

\section{The Second Subject}

The students tried to solve a given problem using several steps. In the step 1, the students used the auxiliary line and described a line parallel to the $\mathrm{AB}$ line and having a distance of $1 \mathrm{~cm}$ with $\mathrm{AB}$ line. Furthermore the student gave a symbol $\mathrm{E}$ on the intersection of the auxiliary line with the $\mathrm{AB}$ line as the following Figure 4.a. 


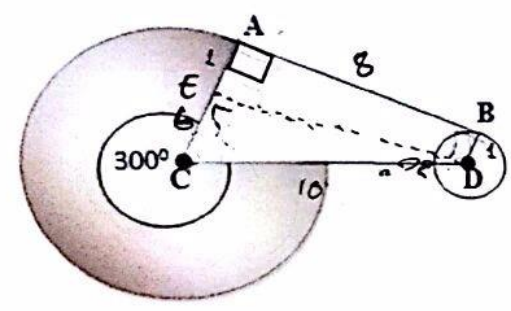

Figure 4.a

Step I

After that, the students tried to solve the given problem started by finding the length of EC line by using Pythagoras theorem by using existing information that is the length of $\mathrm{EC}$ line $=$ the length of $\mathrm{AB}$ line that is $8 \mathrm{~cm}$ and the length of $\mathrm{CD}$ line that is $10 \mathrm{~cm}$.

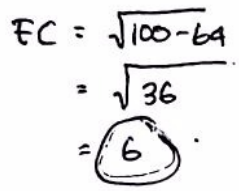

S2: I calculate the length of EC using Pythagoras

Figure 4.b

Step II

The results of using the Pythagoras show that the length of EC line is $6 \mathrm{~cm}$. Subsequently, the students tried to find the length of EC line in different ways to make sure the work has been done. The students calculated the length of EC by using the large angle of CDE obtained by finding a large angle $\operatorname{ECD}\left(360^{\circ}-300^{\circ}=60^{\circ}\right)$ first then obtained a large angle of CDE by way of $180^{\circ}-\left(90^{\circ}+60^{\circ}\right)$ so that it obtained $30^{\circ}$. $30^{\circ}$ angle was used to find the length of EC line by using the ratio of the length of the EC line and the length of CD line so that the EC length is $5 \mathrm{~cm}$.

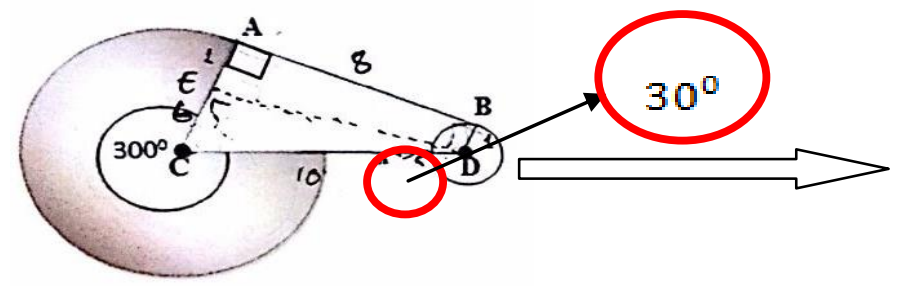

$$
\begin{aligned}
\operatorname{Sin} 30^{\circ} & =\frac{1}{2} \\
& =\frac{E C}{C D}=\frac{E C}{10} \\
E C & =5
\end{aligned}
$$

Figure 4.c

Step III

Based on the results of both ways, the results obtained were different and resulted in the emergence of the student's doubt with the calculations that he did. The students tried to rework it in both ways. The following statement shows that the student performed repeated calculations in both ways. 
S2 : I've tried several times the result is different but yes sir.

The students knew the differences obtained using these two ways but he continued to work to find the shaded area by using the result of the use of Pythagoras theorem to gain the following results.

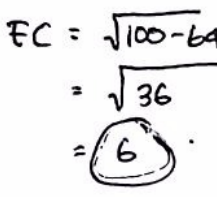

Figure 4.d

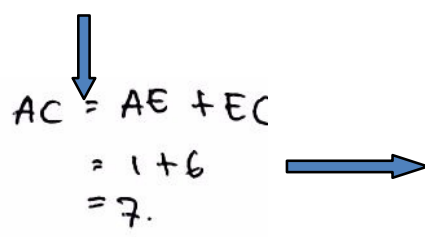

Figure 4.e

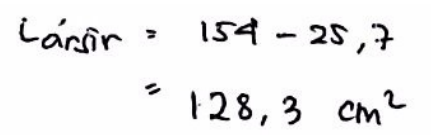

Figure 4.h

Figure 4.d shows that after the students found the length of EC line, he calculated the radius of the circle (in this case the length of AC line), then he calculated the area of the circle by substituting the length of $\mathrm{AC}$ line that has been found into the circle area formula. Next, the students counted the width that is not shaded by using the formula

area of the sector with a large angle of $60^{\circ}$. Finally, he calculated the shaded area width by way of wide area of the circle minus the area that is not shaded.

After the student finisheds writing down all the answers, he never collecteds the answers and showeds the expression of doubt. The researcher askeds the students to collect it but the student said that he was unsure of what has been answered. Here is a snippet of the student interviews with the researchers.

$P:$ Why did you hesitate?

S2: Yes i did, because if you use Pythagoras the result will be different from using trigonometry.

$P$ : Why did you answer like this?

S2: Yes because it is better if using Pythagoras.

$P:$ Why did you tell me that the theorem of Pythagoras is more correct?

S2: Yes because the Pythagoras can be used to find the length of one side if the lengths of the other two sides are known in the right triangle.

$P:$ so is it wrong, if you use trigonometric rule?

S2: No, it isn't, because I am taught in the school to use Pythagoras theorem. The trigonometry was taught at the Olympic extracurricular event. 
From the interview result, it appears that the student still chooses to continue his work even though he knows there are contradictory results. That's because the habits in the classroom use the Pythagoras theorem. Students do not dare to mention that the problem given does not make sense because in that case there is a command to determine the area of shaded area and the class (culture) habits of the students have never been invited to evaluate the truth of a problem, so that students do until found wide area shaded.

\section{DISCUSSION}

\section{The First Subject}

The first subject indicates that there were high doubts (this is proven by the response of students who directly questioned the correctness of the problem before attempting to solve it) so that the student made delays in making decisions to solve the given problems. This is consistent with Nestadt's (2016) opinion that under the conditions of high uncertainty, individuals experience delays in reaching decisions (Nestadt et al., 2016). The doubts over the problem are due to cognitive conflicts in the first subject. It corresponds to Campbell's (2010) argument that one's skepticism can arise if one has a preconception (prima facie) of a truth but then receives something contrary to something which has been believed in (Campbell, O'Rourke, \& Silverstein, 2010). In the child's long term memory, the cognitive structure that has been formed (Prima Facie) is a right

triangle in which one angle region has a large angle of $30^{\circ}$ then the ratio of the sides that meets is $1: \sqrt{3}: 2$ then the student received a mathematical problem with the

structure a problem in which there is a right triangle with one of the angles of $30^{\circ}$ but the known two-sided ratio is 8:10.

This doubt results in the student's attitude not to solve the problem because it is assumed that the matter is not true. The student's decision not to solve the problem is accompanied by a logical reason according to the procedure in mathematics. He showed some conflicting information to make the length of a line equal to three different lengths. When the students showed conflicting information, it appears that he was reflecting by repeating the procedures that had been done repeatedly. Student reflection serves to change situations where there are doubts arising from cognitive conflicts in a fixed situation (Dewey, 1993) in the determination of the mathematical problem.

Here is a phase involved in skepticism and decision making on the ill-logical mathematics problem on the first subject:

1. Cognitive conflicts:

2. Skepticism of information on ill-logical mathematics problems

3. Reflective

4. Proving the doubt that arises: (a) performing procedural calculations and (b) comparing with the other alternatives in procedural calculations

5. Decision-making: do not do what is ordered in the problem because it assumes that the problem is not true. 


\section{The Second Subject}

The student initially did not doubt the correctness of the given problem, but after trying to solve the problem, the student found the different results by using two different ways. The use of two different ways arises because of the doubts in the results obtained by using one way so that the student reflected on his work by comparing the results of the first and second ways. On that basis, it appeared that there were doubts in the truth of available the information. These doubts arose after the student knew that using different ways produced different results as well. This is in accordance with the opinion of Campbell et al. (2010) that if two or more conclusions are contradictory, it is irrational for a person to believe in any of these conclusions. The resulting chaos caused the student to reflect on the calculations performed (back to tracking). Back to tracking is done to determine whether the belief is correct by tracking what has been done (Campbell et al., 2010). These doubts require constant reinforcement (Nestadt et al., 2016).

After continuous checking, there were still some self-doubts, however, the student continued to work to answer the questions of the matter with the consideration that the school always uses the first way compared to the second way. The habits in the school causes the student to make decisions to work on and get answers to the questions. Another factor caused the students to make the decision to do the problem is because in the school he was never invited by the teacher to correct the truth of a problem. In school, the teachers always demand the student to solve the existing problems, so the student continued to calculate the area of the shaded area even though there was actually doubt in his heart. In this case, it appeared that the social environment is very influential in terms of decision making (Kotler, 2003; \& Engel, 1994). The decision that was taken by the student to continue their work in solving the problem was still shrouded by the sense of rational arousal.

Here is a phase involved in skepticism and decision making on the ill-logical mathematics problem on the second subject:

1. Doing what is ordered in the problem: performing procedural calculations

2. Reflection

3. Proving the truth of what is done: comparing with other alternatives in procedural calculations

4. Skepticism of information on ill-logical mathematics problems

5. Reflection: reviewing what has been done

6. Proving the doubt that arises: (a) performing procedural calculations and (b) comparing with the other alternatives in procedural calculations

7. Decision-making: continuing to do what is ordered by choosing an alternative calculation influenced by the social environment (local culture).

8. A skeptic of information in the ill-logical mathematics problem is still present in the student.

From the first and second subjects it appears that there are two causes of skeptic: (1) the presence of cognitive conflict (CC) and (2) the existence of two conflicting (contrary) 
outcomes (BK). Skeptic (SK) can result in reflection. The performed reflection (RF) can be: (1) repetition of what has been done (BT) and (2) comparison of the results of how to do with the results of different ways (BD). The reflection lays on the decision making. Decision-making (DM) is done to solve the ill-logical mathematics problem or to not solve the ill-logical mathematics problem. A person who takes the rationale will decide not to finish the ill-logical mathematics problem. Someone who puts forward the social (cultural) environment will continue to complete the ill-logical mathematics problem although there are still doubts in his mind. The social environment (SE) in this issue is the habit in the school to solve any given problem (rather than judging the wrong or true problem).

In general, the phases involved in skeptic and decision making on the ill-logical Mathematics problem can be seen in Figure 5 as follows:

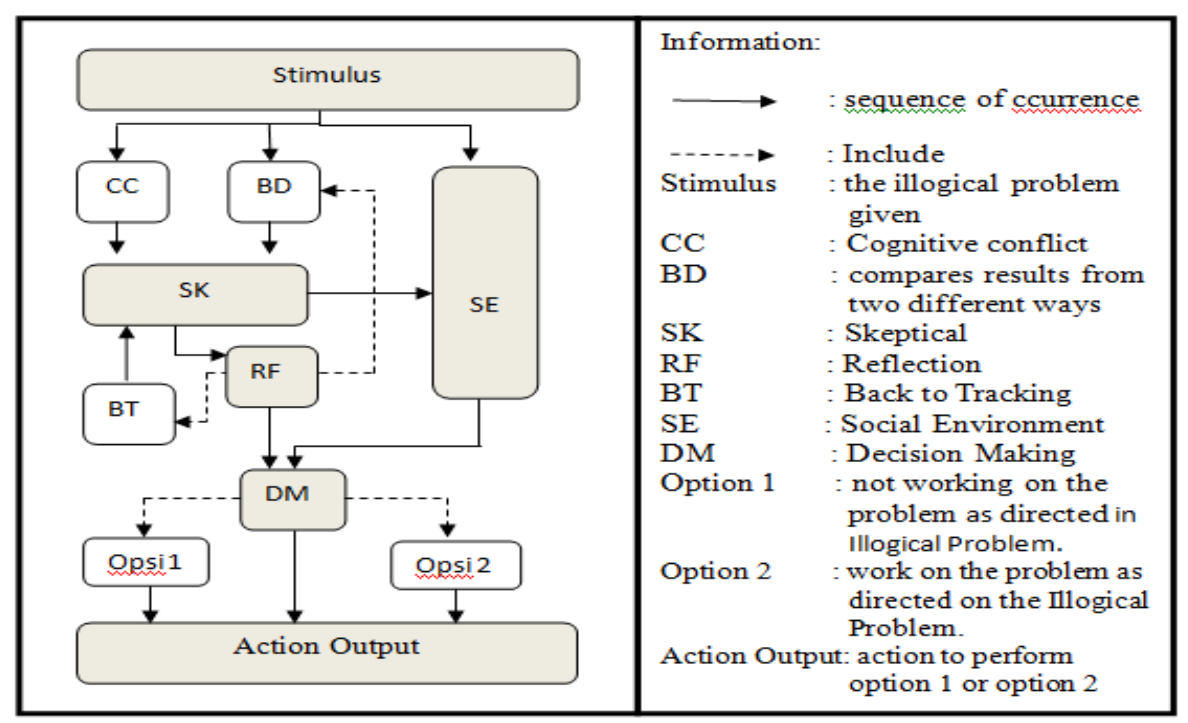

Figure 5

Phases involved in skepticism and decision making on the ill-logical mathematics problem

\section{CONCLUSION}

Based on the results and discussion, the conclusions of this article are as follows:

a. there are two causes of skepticism: (1) the existence of cognitive conflict and (2) the existence of two conflicting outcomes,

b. the phase involved in skeptic and decision making on ill-logical mathematics problem are acceptance of stimulus, skeptic, reflection and decision making as can be seen in Figure 5. In that phase, it is seen that there are two things that influence decision making namely rationality and social environment. 
Based on the research that has been done by the researchers, there are some unanswered questions. The question is likely to be further researched. The question is "how to shape the skeptic attitude of students who can lead to critical thinking?".

\section{REFERENCES}

Angeli, C., \& Valanides, N. (2009). Instructional effects on critical thinking: Performance on ill-defined issues. Learning and Instruction, 19(4), 322-334. https://doi.org/10.1016/j.learninstruc.2008.06.010

As'ari, A. R., \& Irawan, E. B. (2016). Variasi Kontruk Dalam Pembelajaran Matematika (pp. 1-20). Malang: CV Bintang Sejahtera.

As'ari, A. R., Mahmudi, A., \& Nurlaelah, E. (2017). Our Prospective Mathematic Teachers Are Not Critical Thinkers Yet, 8 (2)(February), 145-156. https://doi.org/10.22342/jme.8.2.3961.145-156

Azwar, S. (2010). Metode penelitian. Yogyakarta: Pustaka Belajar

Bell, R., \& Loon, M. (2015). Reprint: The impact of critical thinking disposition on learning using business simulations *. International Journal of Management Education, 119-127. https://doi.org/10.1016/j.ijme.2015.10.003

Biber, A. C., Tuna, A., \& Incikabi, L. (2013). An investigation of critical thinking dispositions of mathematics teacher candidates, 4(February), 109-117.

Bie, H. De, Wilhelm, P., \& Meij, H. Van Der. (2015). Ac ce p te d t. Thinking Skills and Creativity, 0-41. https://doi.org/10.1016/j.tsc.2015.04.001

Campbell, J. K., O’Rourke, M., \& Silverstein, H. S. (2010). Knowledge and Skepticism. London: MIT Press.

Chen, P., Tolmie, A. K., \& Wang, H. (2017). Growing the critical thinking of schoolchildren in Taiwan using the Analects of Confucius. International Journal of Educational Research, (2016). https://doi.org/10.1016/j.ijer.2017.02.002

Cheng, M. H., May, \& Wan, Z. H. (2017). Exploring the effects of classroom learning environment on critical thinking skills and disposition: A study of Hong Kong 12 th graders in Liberal Studies. Thinking Skills and Creativity. https://doi.org/10.1016/j.tsc.2017.03.001

Dewey, J. (1993). How We Think, A Restatement of The Relation of Reflective Thinking to The Educative Process. London; D.C. Healt and Company.

Douglas, E. P., Koro-ljungberg, M., Mcneill, N. J., Malcolm, Z. T., \& Therriault, D. J. (2012). European Journal of Engineering Moving beyond formulas and fixations: solving open-ended engineering problems. European Journal of Engineering Education, $\quad 37 \quad$ (6) (December), 37-41. https://doi.org/http://dx.doi.org/10.1080/03043797.2012.738358

Engel, J. F., Blackwell, R.D \& Miniard, P.W. (1994). Perilaku Konsumen. Jakarta: Bina Rupa

Ennis, R. H. (2011). The Nature of Critical Thinking: An Outline of Critical Thinking Dispositions, $1-8 . \quad$ Retrieved from http://faculty.education.illinois.edu/rhennis/documents/TheNatureofCriticalThinking_51 


\section{1_000.pdf}

Facione, P. A. (1990). Critical Thinking: A Statement Of Expert Consensus For Purposes Of Educational Assessment And Instruction. Educational Resources Information Center(ERIC). Retrieved from Dokumen Reproduction Service No. ED 315423

Facione, P.A, Facione, N. (1992). The California Critical Thinking Dispositions Inventory (CCTDI); and the CCTDI Test manual. Millbrae, CA: California Academic Press

Facione, P. A. (2000). The Disposition Toward Critical Thinking: Its Character , Measurement, and Relationship to Critical Thinking Skill The Disposition Toward Critical Thinking: Its Character, Measurement, and Relationship to Critical Thinking Skill, 20(1), 61-84.

Hocking, I., \& Vernon, D. (2017). The right tool for the right task: Structured techniques prove less e ff ective on an ill-de fi ned problem fi nding task, 26(November 2016), 84-91. https://doi.org/10.1016/j.tsc.2017.08.001

King, P.M. \& Kitchener, K.S. (1994).Developing reflective judgment: Understanding and promoting intellectual growth and critical thinking in adolescents and adults. San Francisco: Jossey-Bass

Kotler, P. (2003). Managemen Pemarasan. Edisi 11. Jakarta: PT Indeks.

Ku, K. Y. L., Lee, V. S. L., \& Ellis, J. (2017). Using Artwork as Problem Context in Generic Critical Thinking Instruction: A Strategy for Thoughts. Thinking Skills and Creativity. https://doi.org/10.1016/j.tsc.2017.07.001

Lynch, C., Ashley, K. D., Pinkwart, N., \& Aleven, V. (2009). Concepts , Structures , and Goals: Redefining. International Journal of Artificial Intelligence in Education 19(3), 19(3), 253-266.

Nestadt, G., Kamath, V., Maher, B. S., Krasnow, J., Nestadt, P., Wang, Y., ... Samuels, J. (2016). Doubt and the decision-making process in obsessive-compulsive disorder. Medical Hypotheses, 96, 1-4. https://doi.org/10.1016/j.mehy.2016.09.010

Özkahraman, Ş. (2012). Investigation of Critical Thinking Disposition in a University Hospital of Nurses Working in Turkey PhD RN, Assistant Professor, 2(3), 143-149.

Simatwa, E. M. W. (2010). Piaget's theory of intellectual development and its implication for instructional management at pre- secondary school level, 5(July), 366371.

Taube, K. T. (1997). Written Critical Thinking Test Linked references are available on JSTOR for this article: Critical Thinking Ability And Disposition As Factors Of Performance On A Written Critical Thinking Test, 46(2), 129-164. Retrieved from http://www.jstor.org/stable/27797335

Udi, E. A., \& Cheng, D. (2015). Developing Critical Thinking Skills from Dispositions to Abilities : Mathematics Education from Early Childhood to High, (March), 455-462. https://doi.org/http://dx.doi.org/10.4236/ce.2015.64045 